\title{
Evaluation Of Team Compliance To Apply Who Surgical Safety Checklist On Major Surgical Operation In Surgical Department of PKU Muhammadiyah Bantul Hospital
}

\author{
Siti Karlina \\ Master of Hospital Management - Universitas Muhammadiyah Yogyakarta \\ Elsye Maria Rosa \\ Master of Hospital Management - Universitas Muhammadiyah Yogyakarta \\ Mariska Urhmila \\ Master of Hospital Management - Universitas Muhammadiyah Yogyakarta
}

\begin{abstract}
ABSTRAK
Background: Procedure of major surgery at PKU Muhammadiyah Bantul Hospital already has a standard from medical committee in surgical department, but there is no evaluation to assess safety related to surgical procedure. Aim: To assess surgical team compliance to apply surgical safety checklist, especially part of sign in, time out, and sign out phase at major surgery and to find strategy to minimize obstacles about implementation of surgical safety checklist in operating room of PKU Muhammadiyah Bantul Hospial. Method: This study using sequential explanatory design. The subjects were all staffs who were work in the operating room, then nurse and doctor were assessed about surgical safety checklist including sign in, time out and sign out. Data collection was done gradually for 7 days in the surgery instalation of PKU Muhammadiyah Bantul Hospital. Instrument: This study used WHO surgical safety checklist which was divided into three phases: before induction (Sign In), before the skin incision (Time Out), and before the patient leaves the operating room (Sign Out). If the procedure is not completely done then the point is 0 and if completely done the point is 1 . Result: There were 30 surgery sessions in urology surgery $7(23,33 \%)$, obgyn $6(20 \%)$, orthopedic $2(6,67 \%)$, oncology $3(10 \%)$, digestive $6(20 \%)$, and other operations $6(20 \%)$. The lowest compliance to filling the checklis was the time of sign in $4(13.3 \%)$ of 30 operating sessions. The lowest compliance during time out was filling the time that was only filled as much as $3(10 \%)$, and insertion of radiology imaging that was just as much as $5(16,7 \%)$. The lowest compliance when signed out was the time of sign out $(10,0 \%)$ and post op diagnosis $(16,7 \%)$. Conclusion: Surgical Safety Checklist filling either Sign In, Time Out, or Sign Out at Surgery Instalation PKU Muhammadiyah Bantul Hospital was included in less obedient criteria.
\end{abstract}

Keywords: Surgical Safety Checlist, Compliance, PKU Muhammadiyah Bantul Hospital

\section{BACKGROUND}

One of the most thing to improve hospital quality is to implement a patient safety program. Patient safety is a condition that patient free from injury that should not occur or is free of potential injury that may occur related to health care [1].

Patient safety is a system where the hospital makes the patient's care more secure. These include: risk assessment, identification, and management of issues related to patient risk, incident reporting and analysis, learn from incident, and implementation of the solutions to minimize risks [2]. 
Recording of near miss incidents in Indonesia was still not well documented. The operating room is the most vulnerable place where is the incident happen compared to other units in a hospital, because operating rooms are complex and high-risk places [3].

In January 2009, WHO in the World Alliance for Patient Safety made Surgical Safety Checklist (SSC) as a tool used for clinicians in the operating room to improve the surgery safety, reduce mortality, and reduce surgical complications [4]. The use of SSCL WHO can enhance teamwork in the operating room. Surgical safety checklist has been widely used in the world and proven to reduce mortality and complications due to surgery.

Obedience is a attitude that always do the command. Obedience is behavior according to rules and discipline. Professional officer compliance is behavior as a professional to a suggestion, procedure or regulation to be done or obey $[5,6,7]$.

Based on preliminary study on August 24, 2016 with interview method, the head of Surgical Department of PKU Muhammadiyah Bantul Hospital said the hospital has been implementing surgical patient safety since two years ago but not yet doing well. He said just $80 \%$ of the new surgical team performed a surgical safety checklist. From the observasion, we can saw there were some points that were not completely done. For example was in the "time out" phase, the surgical team did not introduce themselves verbally, the surgical team did not confirm verbally about the patients identity and diagnosis, in the "sign out" phase, nurse did not verbally confirm the number of instruments used.

Practice of major surgical procedure at PKU Muhammadiyah Bantul Hospital has already standardized form medical committee in the surgical section, but has not been evaluated related to surgical procedure. Based on this background, this study was aimed to find out the compliance of surgical team in applying surgical safety checklist "sign in", "time out", and "sign out" phase at major surgical operation and to find strategies to overcome obstacles in applying surgical safety checklist in operation room of PKU Muhammadiyah Bantul Hospital.

\section{Research Design}

\section{RESEARCH METHOD}

Sequential explanatory method was used in this study. This method was done by collecting and analyzing quantitative data in the first stage, then analyze the qualitative data in the second stage, the next step was analyzing the whole data to get the conclusion from analysis $[8,9,10]$.

Quantitative methods were used to find measurable information about the implementation of surgical safety checklist and qualitative methods were used to obtain information about evaluation of surgical safety checklist in the operating room PKU Muhammadiyah Batul Hospital.

\section{Research Subject}

We recruit health workers who work in the operating room as subject, ie all of surgical team the central surgical department. The object was the compliance of nurse and anesthesiologist to fill the surgical safety checklist including sign in, time out and signing out. Data collecting is done gradually for 7 days in the central surgery department of PKU Muhammadiyah Bantul Hospital. 


\section{Instrument \\ Observasion}

Researcher will directly observe the implementation of surgical safety checklist in the operating room. Operating Room of PKU Muhammadiyah Bantul Hospital used surgical safety checklist from WHO which has been translated into Indonesian language. Surgical safety checklist was divided into three stages, before induction (Sign In), before skin incision (Time Out), and before the patient leaves the operating room (Sign Out). In the three research cycles, all points on this checklist should be filled in time, for example the completion of checklist "sign in" must be done before induction. The scoring was 0 if not complete, and got 1 point if complete.

\section{Interview Guide}

This tools was used to interview an anesthesiologist. Questions in this interview was about the implementation of surgical safety checklist, obstacles and suggestions for improvements to existing surgical safety checklists [11].

\section{Interview Tools}

Standard sationery was used to interviews the respondents.

\section{Variables}

This variable research was the compliance of surgical safety checklist filling. Indicators to measure compliance of surgical safety checklist was the completion of checklist sign in, time out, and sign out.

"Sign in" were performed before induction of anesthesia, including: identity confirmation, surgical location, surgical procedure, inform consent, surgical location marks, preparation of anesthetic machine and drugs, insertion of pulse oximetry, checking allergy history, difficulty breathing, risk of blood loss $>500 \mathrm{ml}$.

"Time Out" were performed before skin incisions, team members introduced their names and roles respectively, the nurse confirmed the patient, location, and procedure, anticipating the occurrence of the crisis, whether critical / unexpected steps, duration of operation, anticipation of blood loss, sterilization has been confirmed, prophylactic antibiotics have been given in the last 60 minutes, and imaging placement.

"Sign out" variables were performed before the patient leaves the operating room, including confirmation from nurse that must be doing verbally with the team, the name of the procedure, instrument calculation, labeled specimen, identify various equipment problems, aand at the final stage before discharge from safety checks

\section{Overview of Central Surgical Department}

\section{RESULT}

Central Surgical Department of PKU Muhammadiyah Bantul Hospital consists 3 operating rooms. Type of operation which performed at OR was generally an elective or planned operation. Central Surgical Deparment of PKU Muhammadiyah Bantul Hospital already has an standard for patient safety procedures such as the handover of preoperative and patient identification, while for the implementation of surgical safety checklist has been going for two years. Central Surgery Department has been doing 2,994 operation, with an average 250 operations each month from 2014-2015. 


\section{Respondent Characteristic}

The subject of this research is the surgery session at Central Surgery Department of PKU Muhammadiyah Bantul Hospital which was conducted between the 1st and 6th of February 2016. There were 30 operating sessions with details shown in table 4.1

Tabel 4.1

Type of Surgery in Surgery Department

\begin{tabular}{lrr}
\hline Type of Surgery & Total & Percentage \\
\hline Urology & 7 & $23.33 \%$ \\
ObsGyn & 6 & $20 \%$ \\
Orthopaedic & 2 & $6.67 \%$ \\
Oncology & 3 & $10 \%$ \\
Digestif & 6 & $20 \%$ \\
Others & 6 & $20 \%$ \\
\hline
\end{tabular}

The kind of surgical operations in this study were: urology surgery includes TURP and removal of bladder tumor, obstetric and gynecological parts including cesarean section and ovarian tumor surgery, orthopedic section includes ORIF and ulcer debridement, oncology includes excision of subcutaneous and malignant tumors basal cells, while the digestive surgery includes apendectomy and hernia repair.

Implementation of patient safety procedures assessed by looking at the completion of the medical record that includes the completion of identity, sign in checklist , time out checklist , and sign out checklist.

\section{Completeness of Patient Identity}

One strategy to reduce surgical errors is to identify patients correctly including reconfirmation of patient identity before surgery begins. The degree of compliance of the patient's identification on the operating supervisory sheet is shown in Table 4.2

Tabel 4.2

Completeness of Patient Identity

\begin{tabular}{lrrrr}
\hline & \multicolumn{4}{c}{ Checklist Completion } \\
\cline { 2 - 5 } \multicolumn{1}{c}{ Identity Item } & \multicolumn{2}{c}{ Obey } & \multicolumn{2}{c}{ Disobey } \\
\cline { 2 - 5 } & Total & \multicolumn{1}{c}{ Total } & \multicolumn{1}{c}{$\%$} \\
\hline Patient's name & 28 & $93.3 \%$ & 2 & $6.7 \%$ \\
Pasient's sex & 29 & $96.7 \%$ & 1 & $3.3 \%$ \\
Patient's age & 13 & $43.3 \%$ & 17 & $56.7 \%$ \\
Medical Record Number & 24 & $80.0 \%$ & 6 & $20.0 \%$ \\
Nama of Procedure & 15 & $50.0 \%$ & 6 & $20.0 \%$ \\
Date of Operation Done & 16 & $53,3 \%$ & 14 & $46.7 \%$ \\
Surgeon / Anesthethist's name & 7 & $23,3 \%$ & 23 & $76.7 \%$ \\
\hline
\end{tabular}

The results showed that all the supervisory sheets were not complete in the identity items. Identification of the patient's name is very important but there were $2(6.7 \%)$ of 30 surgeries that do not written patient's name. The lowest compliance was on the surgeon and anesthetist name, ie 7 (23.3\%) surgery sessions.

\section{Compliance of sign in checklist form}

Sign in is the phase before induction of anesthesia. Coordinators check verbally about time, pre-operation diagnosis, patient preparation, instrument, and risk assessment. Sign in phase compliance level in this study was shown in Table 4.3 
Table 4.3

Compliance of sign in checklist form

\begin{tabular}{|c|c|c|c|c|}
\hline \multirow{3}{*}{ Sign In Item } & \multicolumn{4}{|c|}{ Checklist Completion } \\
\hline & \multicolumn{2}{|c|}{ Obey } & \multicolumn{2}{|c|}{ Disobey } \\
\hline & Total & $\%$ & Total & $\%$ \\
\hline Time to start sign in & 4 & $13.3 \%$ & 26 & $86.7 \%$ \\
\hline pre-operative diagnosis & 24 & $80.0 \%$ & 6 & $20.0 \%$ \\
\hline $\begin{array}{l}\text { Patient has been informed about bracelet identity gelang, } \\
\text { site of surgery, procedure, informed consent about } \\
\text { surgery/anesthetion }\end{array}$ & 30 & $100.0 \%$ & 0 & $0.0 \%$ \\
\hline Marking in surgery site & 26 & $86.7 \%$ & 4 & $13.3 \%$ \\
\hline Preparation of machine and anesthetic drug & 26 & $86.7 \%$ & 4 & $13.3 \%$ \\
\hline Pulse oximeter sudah terpasang dan berfungsi & 19 & $63.3 \%$ & 11 & $36.7 \%$ \\
\hline History of allergic reaction & 26 & $86.7 \%$ & 4 & $13.3 \%$ \\
\hline $\begin{array}{l}\text { Assessment of respiratory problem / aspiration risk and use } \\
\text { respiratory supporting machine }\end{array}$ & 28 & $93.3 \%$ & 2 & $6.7 \%$ \\
\hline Assessment of blood loss risk >500 ml (7 ml/kgBB in child) & 27 & $90.0 \%$ & 3 & $10.0 \%$ \\
\hline $\begin{array}{l}\text { Consideration about double intravenous access / central } \\
\text { access and fluid therapy plan }\end{array}$ & 26 & $86.7 \%$ & 4 & $13.3 \%$ \\
\hline
\end{tabular}

The results showed that at 30 sessions the surgery always identifies the patient's bracelet, the location of the operation, and has conducted informed consent to the patient regarding the surgical procedure and anesthesia. However many of the items are not filled, the lowest compliance was about time to start sign in phase, ie 4 (13.3\%) of 30 operating sessions. While the patient's risk assessment was performed with an adherence level above 85\%, ie allergy history assessment (86.7\%), respiratory assessment / aspiration risk (93.3\%), blood loss risk assessment (90.0\%), and consideration for double access intravenous (86.7\%).

\section{Compliance of time out checklist form}

Time out is the phase that every member of the operating team introduces themselves and the role, confirmation about surgery site, confirmation about prophylactic antibiotics, and the anticipation of critical events. Level of adherence phase time out in this study seen in table 4.4.

Table 4.4

Compliance of time out checklist form

\begin{tabular}{|c|c|c|c|c|}
\hline \multirow{3}{*}{ Time Out Item } & \multicolumn{4}{|c|}{ Checklist Completion } \\
\hline & \multicolumn{2}{|c|}{ Obey } & \multicolumn{2}{|c|}{ Disobey } \\
\hline & Total & $\%$ & Total & $\%$ \\
\hline Time out time & 3 & $10.0 \%$ & 27 & $90.0 \%$ \\
\hline Introducing about name and role of each operation team & 28 & $93.3 \%$ & 2 & $6.7 \%$ \\
\hline re-confirmation of the procedure and the surgery site & 28 & $93.3 \%$ & 2 & $6.7 \%$ \\
\hline $\begin{array}{l}\text { Confirmation that antibiotic has been given } 30 \text { minutes before, } \\
\text { name and dose. }\end{array}$ & 20 & $66.7 \%$ & 10 & $33.3 \%$ \\
\hline Anticipation about critical event review from surgeon & 8 & $26.7 \%$ & 22 & $73.3 \%$ \\
\hline Anticipation about critical event review from anesthetic team & 8 & $26.7 \%$ & 22 & $73.3 \%$ \\
\hline Anticipation about critical event review from nurse team & 11 & $36.7 \%$ & 19 & $63.3 \%$ \\
\hline Insertion of X-Ray/CT-Scan/MRI imaging. & 5 & $16.7 \%$ & 25 & $83.3 \%$ \\
\hline
\end{tabular}

The results showed that introducing about name and role of each operation team was quite good, including the re-confirmation of the procedure and the surgery site that is about 93.3\%. However, many items are not filled in during the time out which is only filled as much as 3 $(10 \%)$ and confirmation for radiology imaging that was $5(16,7 \%)$. Anticipation of a critical incidence was quite low from the review of surgeons $(26.7 \%)$, review of the anesthesia team $(26.7 \%)$, and review of the nurse team $(36.7 \%)$. 


\section{Compliance of sign out checklist form}

Sign out is the phase that the surgical team reviewing the operations that have been performed eg instrument completeness, specimen labeling, post-operative diagnosis and other problems. The level of adherence to the sign out phase in this study is shown in Table 4.5 .

Table 4.5

Compliance of sign out checklist form

\begin{tabular}{lrrrc}
\hline \multirow{2}{*}{\multicolumn{1}{c}{ Sign Out Item }} & \multicolumn{3}{c}{ Checklist Completion } \\
\cline { 2 - 5 } & \multicolumn{2}{c}{ Obey } & \multicolumn{3}{c}{ Disobey } \\
\cline { 2 - 5 } & Total & \multicolumn{1}{c}{ Total } & $\%$ \\
\hline Sign Out Time & 3 & $10.0 \%$ & 27 & $90.0 \%$ \\
Post operasi diagnosis & 5 & $16.7 \%$ & 25 & $83.3 \%$ \\
Name of procedure that has been done & 22 & $73.3 \%$ & 8 & $26.7 \%$ \\
Calculating instrument, spons, and needles & 22 & $73.3 \%$ & 8 & $26.7 \%$ \\
Speciment has been labeled & 23 & $76.7 \%$ & 7 & $23.3 \%$ \\
Write down about machine problem & 21 & $70.0 \%$ & 9 & $30.0 \%$ \\
Surgery, anesthesiologisy, and nurse discuss about main & 19 & $63.3 \%$ & 11 & $36.7 \%$ \\
problem & & & & \\
\hline
\end{tabular}

The results showed that most disobediently was sign out item. The lowest adherence was the filling time of sign out $(10.0 \%)$ and postoperative diagnosis $(16.7 \%)$. Digestive surgery has a low completion filling rate on Time Out items (33.3\%) and Sign Out (38\%). Similar to the pattern of filling in urology surgery with Time Out completion of 37.5\% and Sign Out $42.8 \%$. Low filling completion in Oncology Surgery is only found on Sign Out items (25\%). Completion was best seen in orthopedic surgery and obsgyn surgery with completion of all items above $50 \%$.

In general, orthopedic surgery and obstetrics surgery has the highest level of completion. In addition, each type of operation has its own pattern in terms of the proportion of incomplete items of filling.

\section{Subjek Characteristic}

\section{DISCUSSION}

From 30 surgical sessions observed, the most session was urologic surgery at 7 sessions (23.3\%), followed by 6 digestive surgery (20\%) and obstetric-gynecology surgery 6 sessions $(20 \%)$. This result was in accordance with the prevalence of diseases that require surgical action in Indonesia.

Based on the results of Riskesdas 2013 showed caesarean section in Indonesia was about $19.9 \%$ of total deliveries. Then in the urology section, BPH prevalence was $40 \%$ at $50-60$ years old and $90 \%$ at the age of $80-90$ years. While acute appendicitis was still the most common cause of acute abdomen and one of the most common causes of emergency surgery in the emergency department. The lifetime prevalence for acute appendicitis was about one in seven. While the incidence of acute appendicitis was 1.5 to 1.9 per 1000 in the male and female population, and the incidence in men was approximately 1.4 times greater than for women [12, 13].

Based on the results of the study, Surgical Safety Checklist (SSC) at the Central Surgical Department of PKU Muhammadiyah Bantul Hospital has been used but has not run well since most items have low filling compliance. Surgical Safety Checklist in the operating room was used through 3 stages, each corresponding to the time line ie before the induction of anesthesia 
(Sign In), before the skin incision (Time Out) and before removing the patient from the operating room (Sign Out).

\section{Compliance of sign in checklist form}

"sign in" phase performed before the anesthesia induction. The coordinator checks verball about patient's identity, procedure, and ensure the side of the site surgery and must be marked, informed consent, and ensure the pulse oximetry works. Coordinators with anesthetist confirm the patient's risk, whether the patient has a history of allergies, airway difficulty and the risk of blood loss.

The items that have the highest filling compliance were the patient's bracelet identity, surgery site, and being informed and consent regarding surgery and anesthesia procedures. This suggests awareness of patient preparation for surgery was good enough and was considered an important and routine component. It is important to understand that in order to avoid error about wrong surgery location and wrong drug delivery to patients. It needs to be made appropriate monitoring mechanisms, from the coordinator reminded to fill the checklist properly and correctly, reminded to be signed in.

The lowest filling compliance was the patient's risk assessment of allergic history (86.7\%), respiratory rate assessment / aspiration risk (93.3\%), blood loss risk assessment (90.0\%), and consideration of indication double access intravenous (86.7\%). The presence of an anesthesiologist at the time of induction is important. The role of an anesthesiologist was to assess the history of allergies in the patient to be operated and the risk assessment that may occur during and after the operation finished. The absence of an anesthesiologist at sign-in led to poor compliance with the Surgical Safety Checklist [14].

Work experience becomes one of the key factors in patient safety in hospitals. Work experience shows a significant relationship to a patient's safe nursing care. Work experience or duration of work is a factor significantly related to safe surgery compliance as there is a tendency that long-term nurses in hospitals have better ability to perform safe nursing care for patients [15].

\section{Compliance of time out in checklist form}

Compliance for the anticipation of a critical incidence is quite low from the surgeons review (26.7\%), anesthesia team review (26.7\%), and nursing team review (36.7\%). Communication problems such as failure of verbal and non-verbal communication, miscommunication between staff, inter-shifts, undocumented communications, can be false.

Poor communication between physicians and nurses was one of the causes of unexpected incidents or events experienced by patients that can have an impact on patient death, especially in intensive rooms that handle critical conditions in patients $[16,17,18,19]$..

\section{Compliance of sign out in checklist form}

The results showed that sign out item was the most disobediently fill out. The lowest adherence was the filling time of sign out (10.0\%) and postoperative diagnosis $(16.7 \%)$. This happened because less important post-operative awareness. Although this item has passed a critical period on patient safety, surgeon operators, anesthesiologists, and nurses should review what are the key issues to be addressed for further patient care and management $[20,21,22,23,24,25,26]$.

\section{CONCLUSION}

1. Based on result and discussion, it can be drawn conclusion that completion of Surgical 
Safety Checklist either Sign In, Time Out, or Sign Out at Central Surgery Department PKU Muhammadiyah Bantul Hospital included in less obedient criteria.

2. The lowest filling compliance in the "sign in" phase was writing down the start time, ie 4 $(13.3 \%)$ of 30 operating sessions. While the patient's risk assessment was performed with an adherence level above 85\%, ie allergy history assessment (86.7\%), respiratory rate assessment / aspiration risk (93.3\%), blood loss risk assessment (90.0\%), and consideration for double intravenous access (86.7\%).

3. Lowest compliance in "time out" phase was writing down the time that was only filled 3 times $(10 \%)$ and confirmation for radiology imaging display that was filled 5 times $(16,7 \%)$. Compliance for the anticipation of a critical incidence is quite low from the surgeons review $(26.7 \%)$, anesthesia team review (26.7\%), and the nurse team review (36.7\%).

4. Lowest compliance in the "sign out" phase was writing down the finished time $(10,0 \%)$ and post operation diagnosis $(16,7 \%)$.

\section{Reference}

KKP-RS. 2008. Panduan Nasional Keselamatan Pasien Rumah Sakit, Jakarta:

Kemenkes, R. (2006). Panduan Nasional Keselamatan Pasien Rumah Sakit. Kemenkes RI. Jakarta.

Schimpff, S.C. (2007) Improving Operating Romm and Perioperatif Safety: Background and Spesific Recommendations. Surgical Inovation, 14(2) June,pp.127-135

World Health Oraganization (2009) Guidelines for Safe Surgery. Safe Surgery Saves Lives, EHO, Geneva.

Arikunto, S. (2002).ProsedurPenelitian: SuatupendekatanPraktek (Revisi 4) Jakarta: PT Rineka

Hunter, D.,\& Blain, N. (1999). Rates of adverse event among hospital admissions and day surgeries in Ontario from 1992 to 1997. Canadian Medical Association Jurnal , 160 (11), 1585-6

Suprapti, Rosa E. M. , Permatasari Y. 2014. Action Research: Pelaporan Insiden Keselamatan Pasien di IBS RSUP Dr. Soeradji Tirtonegoro Klaten. Muhammadiyah Journal of Nursing

Haynes, A.B., Weiser, T.G., Berry, W.R., et al. (2009) A Surgical Safety Checklist to Reduce Morbidity and Mortality in a Global Population. The New England Journal of Mediciane, 360(5) January 29,pp.491-99

Howard, A.W. 2011. Surgical Safety WHO Surgical Safety Checklist. The New England Journal of Medicine. pp1-6. http://www. hmri.org/research/our-researchers/howard-kaufman. Diakses 03 februari 2015 jam 15.15 WIB.

Lagoo J., Lopushinsky S.R., Haynes A.B., Bain P., Flageole H., Skarsgard E.D., Brindle M.E. 2017. Effectiveness and meaningful use of paediatric surgical safety checklists and their implementation strategies: a systematic review with narrative synthesis. BMJ Open 2017;7:e016298. doi:10.1136/ bmjopen-2017-016298

Baldrige,\& Malcolm. (2009). The Monthly Publication fpr Or Decision Makers or Manager, 3,25.

Riset Kesehatan Dasar Tahun 2013

Ridho K.M., Rosa E.M., Suparniati E. 2013. Analisis Faktor-Faktor Yang Mempengaruhi Kepatuhan Pengisian Rekam Medis Di Rumah Sakit Gigi Dan Mulut Pendidikan UMY. Program Studi Manajemen Rumah Sakit, Universitas Muhammadiyah Yogyakarta

Sendlhofer G, Lumenta DB, Leitgeb K, Kober B, Jantscher L, Schanbacher M, et al. (2016). The Gap between Individual Perception and Compliance: A Qualitative Follow-Up Study of the Surgical Safety Checklist Application. PLoS ONE 11 (2): e0149212. doi:10.1371/journal.pone.0149212

Biffl W.L., Gallagher A.W., Pieracci F.M., Berumen C. Suboptimal compliance with surgical safety checklists in Colorado: A prospective observational study reveals differences between surgical specialties. Patient Safety in Surgery (2015) 9:5. DOI 10.1186/s13037-014-0056-z

Giles K., Munn Z., Aromataris E., Deakin A., Schultz T., Mandel C., Maddern G., Pearson A., Runciman W. 2016. Use of surgical safety checklists in Australian operating theatres: an observational study. ANZ J Surg 87 (2017) 971975. doi: 10.1111/ans.13638 
Rydenfalt C., Johansson G., Odenrick P., Akerman K., Larsson P.A., 2013. Compliance with the WHO Surgical Safety Checklist: deviations and possible improvements. International Journal for Quality in Health Care 2013; Volume 25, Number 2: pp. 182-187

Hurtao J.J.H., Jimenez X., Penalonzo M.A., Villatoro C., Izquierdo S., Cifuentes M. 2012. Acceptance of the WHO Surgical Safety Checklist among surgical personnel in hospitals in Guatemala City. BMC Health Services Research 2012, 12:169

Anderas, T., Joshua, B.P., Susan,P.M., Georgae, T.B. (2010 Impact of Pulse Oximetry Surveillance on Rescue Event Intensive Care Unit Transfers: A Before and after concurrence study, Journal of Anesthesiology, 112(2),pp.282287

Wangoo L., Ray R.A., Ho Y.H. 2016. Compliance and Surgical Team Perceptions of WHO Surgical Safety Checklist; Systematic Review. Int Surg 2016;101:35-49. DOI: 10.9738/INTSURG-D-15-00105.1

Vogts N., Hannam J.A., Merry A.F., Mitchell S.J. 2011. Compliance and quality in administration of a Surgical Safety Checklist in a tertiary New Zealand hospital. N Z Med J. 2011 Sep 9;124(1342):48-58.

Bashford T. Reshamwalla S., McAuley J., Allen N.H., McNatt Z., Gebremedhen Y.D. Implementation of the WHO Surgical Safety Checklist in an Ethiopian Referral Hospital. Patient Safety in Surgery 2014 8:16

Nirbita A., Rosa E.M., Listiowati E. 2017. Faktor Risiko Kejadian Infeksi Daerah Operasi pada Bedah Digestif di Rumah Sakit Swasta. Jurnal Fakultas Kesehatan Masyarakat Volume 11, Issue 2, September 2017, pp. 93-98

Melekie T.B., Getahun G.M., 2015. Compliance with Surgical Safety Checklist completion in the operating room of University of Gondar Hospital, Northwest Ethiopia. BMC Res Notes (2015) 8:361. DOI 10.1186/s13104-015-1338$\mathrm{y}$

McGinlay D., Moore D., Mironescu A. 2015. A prospective observational assessment of Surgical Safety Checklist use in Brasov Children's Hospital, barriers to implementation and methods to improve compliance. Romanian Journal of Anaesthesia and Intensive Care 2015 Vol 22 No 2, 111-121

Asefzadeh, S., Rafiei, S., Saeidi, M., Karimi, M. 2017. Compliance with WHO safe surgery checklist in operating rooms: A case study in Iran Hospitals. Bali Medical Journal 6(3): 465-469. D0I:10.15562/bmj.v6i3i.577 